\title{
Unorganized sources of inorganic dust emissions. Dust suppression at mining enterprises during coal extraction, transportation, transshipment, and storage
}

\author{
Artem Begunov ${ }^{1}$, Vladimir Udovitskiy ${ }^{1 *}$, and Vladimir Kandinskiy ${ }^{1}$ \\ ${ }^{1}$ T.F. Gorbachev Kuzbass State Technical University, Department of Mineral Processing, \\ Vesennya 28, 650000 Kemerovo, Russian Federation
}

\begin{abstract}
Emissions of inorganic dust belong to the group of unorganized emissions that are generated from large areas. Air pollution in the area of coal industry enterprises depends on climatic and mining and geological conditions. The solution of the current mining technical problem of improving the efficiency and safety of mining operations in the development of mineral deposits, which is of great economic and social importance, is inextricably linked with the improvement of methods for fixing dusty surfaces on the objects of the mining complex. Methods of dust suppression are considered and analyzed. Industrial tests of special preventive drugs were carried out and the necessary expenditures of funds and methods of their effective use were determined.
\end{abstract}

\section{Introduction}

Information and Technical Reference Book on the best available technologies for coal mining and processing No. ITS 37-2017 [1], approved by Order of the Government of the Russian Federation No. 2841 of 15.12.2017. [2] identified marker substances for the coal mining industry. Thus, the marker substance for emissions into the atmospheric air for the coal mining industry is defined as inorganic dust.

Emissions of inorganic dust belong to the group of unorganized emissions that are carried out from large areas. Air pollution in the area of coal industry enterprises depends on climatic and mining and geological conditions. Thus, with strong winds, conditions are created for the intensification of the entry into the surface layers of the atmosphere and the movement of dust in them. Even at a wind speed of $2 \mathrm{~m} / \mathrm{s}$, the dry dust is blown away and transported over considerable distances. The construction of high dumps also contributes to the growth of dust emissions into the atmosphere, since the wind speed increases as their height increases [3].

\footnotetext{
* Corresponding author: uvi@kuzstu.ru
} 
The solution of the current mining technical problem of improving the efficiency and safety of mining operations in the development of mineral deposits, which is of great economic and social importance, is inextricably linked with the improvement of methods for fixing dusty surfaces on the objects of the mining complex.

The greatest contribution to air pollution by dust emissions during the development of minerals is made by unorganized open sources of dust emission, the main of which are the dusty surfaces of warehouses, rock dumps, and highways.

Thus, the purpose of this research is to establish effective methods of dust suppression at mining enterprises during the extraction, transportation, transshipment and storage of coal.

Conducting these studies solves the following tasks::

1. Analysis of existing methods of dust suppression in the extraction, transportation, transshipment and storage of bulk materials;

2. Development of a methodology for assessing the dusting of the road surface and the surface of bulk cargo storage stacks at industrial facilities. Determination of the effectiveness of dust suppression means.

3. Review of the experience of using special preventive measures to improve the efficiency of dust suppression;

4. Determination of effective costs and methods of application of special preventive measures.

\section{Research materials and Methods}

The program "Clean Coal-green Kuzbass" is aimed at improving the environmental situation in the region. In this regard, the task of dust suppression at coal enterprises has acquired additional importance. In general, this problem exists not only in the Kemerovo region - it is relevant for Russia as a whole.

Reducing the formation of dust of natural and man-made origin is a serious problem in the coal industry. Fine dust in the suspended state appears during transportation, transshipment, storage, storage of rock mass. Everyone knows that it is dust that provokes many diseases that are usually characterized as "professional". In addition, dusting is an increase in the company's costs for operating equipment, as well as problems with compliance with the environmental legislation of the Russian Federation.

To solve these problems associated with dry and suspended dust, traditionally uses the following methods:

- Installation of filter equipment, including bag filters, scrubbers, cyclones;

- Humidification with ordinary water using mist generators, heating systems;

- Humidification with the use of special preventive means for the treatment of transported dusty materials and polymers, as well as places of mass storage of rock mass and tailing dumps.

There are the following methods of dust suppression using special preventive means:

1. Wetting of the dusting surface with the use of preventive means that have wetting properties;

2. Fog formation in dusty enclosed spaces and open areas of bulk cargo storage (Figure 1) for wetting with the use of preventive measures;

3. Creating a film on a dusty surface by applying a film-forming agent. 


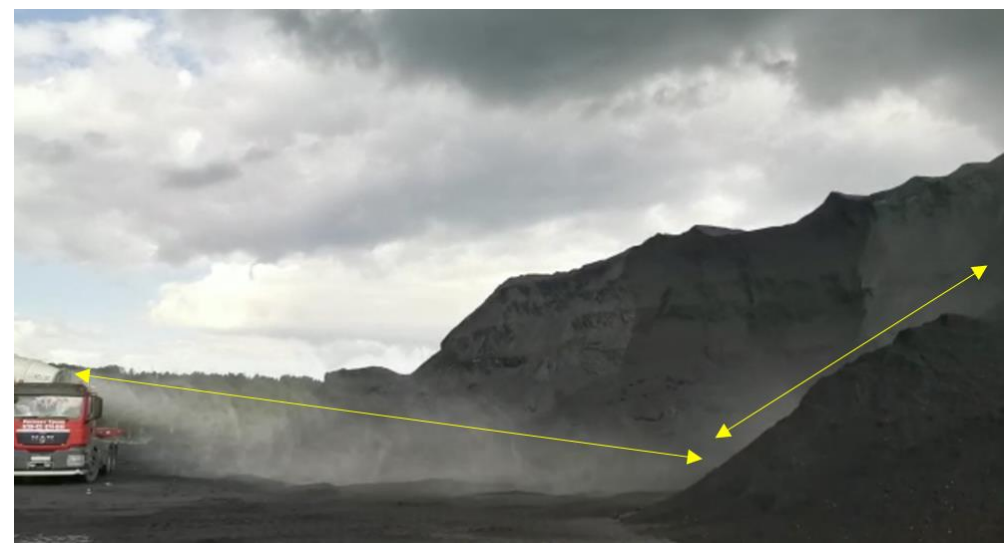

Fig. 1. Processing of the coal warehouse of the Raspadsky mine with the SPD-90 dust suppression system. The direction of the fog flow is as far down as possible. The range is 90 meters. The fog rises on top of the coal stack, which indicates a high-quality atomization of the fine phase.

In 2019-2020, employees of the Engineering Company "BRENT" and the Kuzbass State Technical University named after T. F. Gorbachev conducted industrial tests of the preventive agent "Anti-dust" [7]. With its help, the developers intend to reduce dusting during loading and unloading, transportation, technological sorting and storage of bulk materials at the coal enterprises of Kuzbass (Berezovsky and Mine No. 12 of Stroyservice JSC, Kedrovsky mine of Kuzbassrazrezugol JSC, Raspadsky mine of RUK JSC), Khakassia (Chernogorsky mine of SUEK JSC) and Novosibirsk region (Siberian Anthracite JSC).

\subsection{Method development}

In preparation for the industrial tests, the developers conducted an analysis of the currently available methods for determining dusting, including:

- "Method of calculation estimation of wind erosion and dusting of TPP ash dump", developed by JSC "UralORGES", VNIIOGR, Agrophysical Institute of RASKHN, Yekaterinburg, 1998 [4];

- "Methodology for calculating harmful emissions (discharges) for a complex of openpit mining equipment (based on specific indicators)", developed by the National Scientific Center for Mining Production of the A. A. Skochinsky Institute of Mining, Lyubertsy, 1999 $[5]$

- "Methodological guide for calculating emissions from unorganized sources in the construction materials industry", developed by CJSC "NIPIOTSTROM", Novorossiysk, $2000[6]$.

All the above methods imply a calculated assessment of dusting based on the specific indicators given in them. Basically, we are talking about the assessment of dusting during the design of objects or for a certain reporting period-without instrumental measurements carried out in kind. But in order to evaluate the effectiveness of preventive means of dust suppression, it is necessary to make real measurements in the conditions of industrial enterprises. Therefore, the specialists of the company "BRENT" and KuzSTU developed a technique based on blowing the surface of the bulk material treated with a special preventive agent in the wind tunnel. Instrumental measurement of the material blown off from the dusting surface is performed with a portable portable device PKA-01 or PU-4E (Figure 2). 


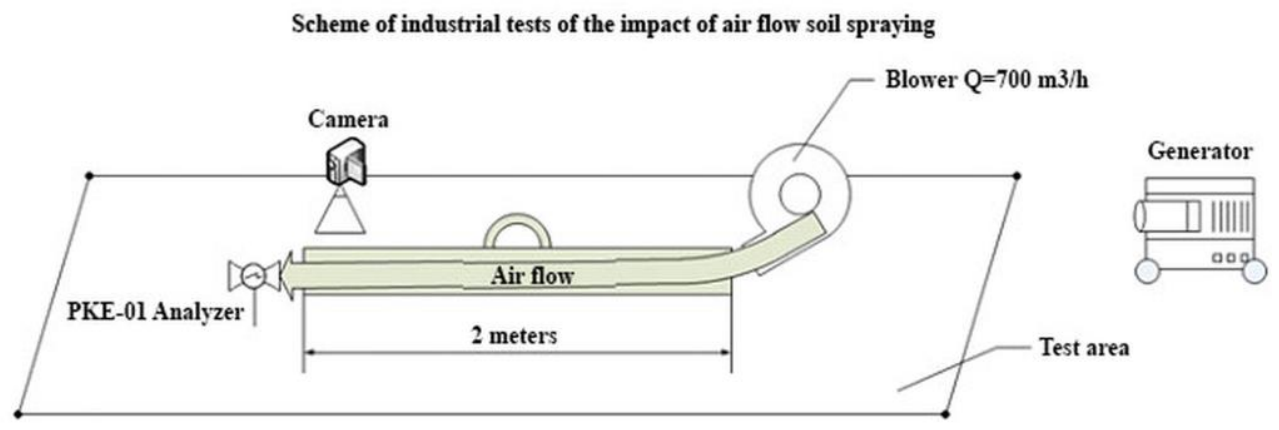

Fig. 2. Installation diagram for instrumental measurement.

Measurements in accordance with the "Methodology for assessing the dusting of the road surface and the surface of bulk cargo storage stacks at industrial facilities. The determination of the effectiveness of dust suppression means " is made as follows: a box was installed on the test surface to directly affect a certain area of the surface and exclude the influence of external factors. At one end of the box, a blower is installed to form an airflow that simulates weather conditions with a wind speed of $25 \mathrm{~m} / \mathrm{s}$. At the other end, the PKA-01 air dust-monitoring device is installed, which analyzes the dust content in the air flow at the outlet of the box. Under the influence of a blower, the airflow simulates the erosive effect of wind on the ground surface at the maximum possible wind loads of up to $25 \mathrm{~m} / \mathrm{s}(90 \mathrm{~km} / \mathrm{h})$. Then the airflow passes through the PKA-01 air dust control device, which shows the dust concentration in the air. Similarly, measurements are made on all areas of the test surface, including the untreated area (control) [13].

The values of dust concentration and weather conditions obtained with the PKA-01 device are recorded in the table and the results are processed.

The efficiency of dust suppression in the treated area relative to the untreated area is determined as follows:

$$
P_{\text {res }}=S_{t r} / S_{\text {untr }} \cdot 100 \%
$$

where $\mathrm{P}_{\text {res }}$ - residual dusting at each test site, \%

$\mathrm{S}_{\mathrm{tr}}$ - dust concentration on the treated area, $\mathrm{mg} / \mathrm{m}^{3}$

$\mathrm{S}_{\text {untr }}$ - dust concentration in the untreated area, $\mathrm{mg} / \mathrm{m}^{3}$

$$
E_{d s}=100 \%-P_{r e s}
$$

$E_{d s}$ - dust suppression efficiency, \%

\subsection{Industrial test materials}

The results of some of the industrial tests carried out at existing coal mining enterprises are presented in Tables $1-3$ and in the figures $3-5[8,9,10,11,12]$. 
Table 1. Results of measurements of the effectiveness of the use of a preventive dust suppression agent at the Chernogorsky mine of SUEK-Khakassia JSC,

\begin{tabular}{|c|c|c|c|c|}
\hline Indicator & $\begin{array}{l}\text { A section of } \\
\text { the roadway } \\
\text { technology. } \\
\text { roads } \\
\text { PKA-01 } \\
\text { device }\end{array}$ & $\begin{array}{c}\text { A section of } \\
\text { the roadway } \\
\text { technology. } \\
\text { roads } \\
\text { PKA-01 } \\
\text { device } \\
\end{array}$ & $\begin{array}{c}\text { A section of } \\
\text { the roadway } \\
\text { technology. } \\
\text { roads } \\
\text { PU-4E device }\end{array}$ & $\begin{array}{c}\text { A section of } \\
\text { the roadway } \\
\text { technology. } \\
\text { roads } \\
\text { PU-4E device }\end{array}$ \\
\hline Type of vehicle & Absorbent & Absorbent & Absorbent & Absorbent \\
\hline $\begin{array}{l}\text { Consumption of funds per } 1 \\
\text { sq. m., liter }\end{array}$ & $\begin{array}{l}0.3 \text { (primary } \\
\text { treatment) }\end{array}$ & $\begin{array}{l}0.05 \quad(\text { re- } \\
\text { processing) }\end{array}$ & $\begin{array}{l}0.3 \text { (primary } \\
\text { treatment) }\end{array}$ & $\begin{array}{l}0.05 \quad(\mathrm{re}- \\
\text { processing) }\end{array}$ \\
\hline $\begin{array}{l}\text { Dust suppression efficiency, } \\
\% \text { (on the } 2 \text { nd day) }\end{array}$ & 99,87 & ---- & 99,79 & ---- \\
\hline $\begin{array}{c}\text { Dust suppression efficiency, } \\
\% \text { (on the } 3 \text { rd day) }\end{array}$ & ---- & 99,48 & ---- & 99,13 \\
\hline $\begin{array}{c}\text { Dust suppression efficiency, } \\
\% \text { (on the } 4 \text { th day) }\end{array}$ & 99,57 & 98,48 & ---- & 97,47 \\
\hline $\begin{array}{l}\text { Dust suppression efficiency, } \\
\% \text { (on the } 5 \text { th day) }\end{array}$ & 98,08 & 97,90 & 96,79 & ---- \\
\hline Average efficiency value, $\%$ & 99,18 & 98,62 & 98,29 & 98,30 \\
\hline
\end{tabular}

\section{Dust suppression efficiency}

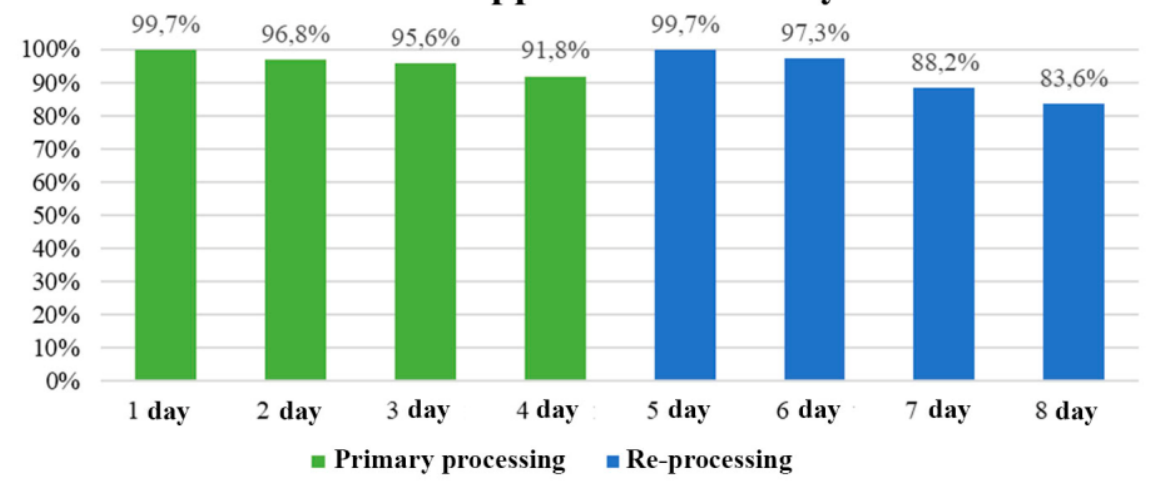

Fig. 3. Results of measurements of the efficiency of dust suppression in the conditions of dirt roads on the territory of the mining branch of LLC "Mine No. 12" (Kiselevsk).

When using the «Methodology for assessing the dusting of the road surface and the surface of bulk cargo storage stacks at industrial facilities. Determination of the effectiveness of dust suppression means») industrial tests of special preventive means were carried out. 


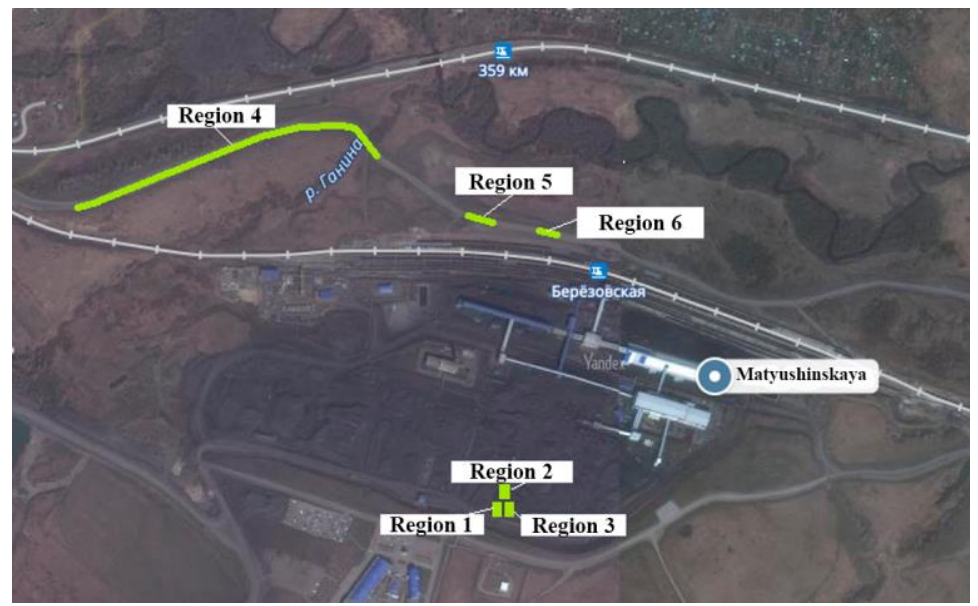

Fig. 4. Situational plan for the location of experimental sites at the Berezovsky mine.

Preventive agent "ANTI-DUST" brand D (absorbent) - a complex of active substances for dust suppression and prevention of freezing of rock mass, dirt roads, coal and rock cones in warehouses and tailing dumps. The principle of operation of this tool is to form a bound layer with the material particles and has high performance characteristics. This tool is used at various stages of the production process of mining, storage, processing of coal and other bulk materials, during loading and transportation of bulk materials. The ANTIDUST agent of the D brand (absorbent) consists of calcium dichloride, special surfactants (including corrosion inhibitors) and water. Special surfactants reduce the surface tension and allow you to cover a large surface of the processed material at the same consumption. Also, the surfactant increases the useful life of the product. Corrosion inhibitors in the composition exclude the negative impact on the metal of technological equipment and gondola cars.
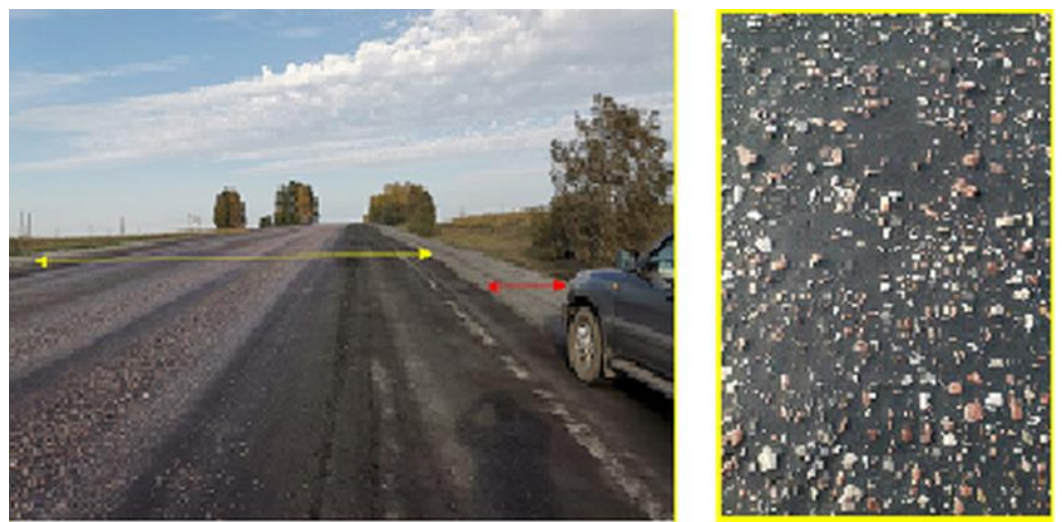

Fig. 5. Treated surface of the technological road JSC "Siberian Anthracite" (Novosibirsk).

The treated road surface in Figure 5 is indicated in yellow color retains moisture on the road surface and binds dust, which is clearly visible in the photo taken 30 hours after treatment. The untreated surface of the roadside is highlighted in red, has a dry and dusty structure. Without special means in the water used in dust suppression, water sprayed on the outer surface of the material dries quickly, and dust can occur again. A special agent dissolved in water penetrates into the thickness of the material and ensures that the particles stick together. The mass and size of the particles are thus increased, and the dust does not 
enter the air. There is a very big difference between dust suppression systems with and without dust suppression additives. Many dry, dusty materials are virtually impervious to clean water. As a result, some of the material will become very wet, and the rest of the material will remain dry and dusty. When adding wetting agents to water and spraying this solution on dry, dusty material, reliable and long-lasting dust suppression is provided.

Table 2. Duration of dust-suppressing properties of the product "ANTI-DUST" and water.

\begin{tabular}{|c|l|c|c|}
\hline $\begin{array}{c}n / a \\
n o .\end{array}$ & \multicolumn{1}{|c|}{ Dust suppression area } & "ANTI-DUST» & Water \\
\hline 1 & Roads and roadsides & $5-7$ days & $2-6$ hours \\
\hline 2 & Processing of bulk materials in bulk & $20-30$ days & - \\
\hline 3 & Storage of bulk materials in cones in open areas & $20-30$ days & - \\
\hline
\end{tabular}

Table 3. Scope of application and consumption ratesof the "ANTI-DUST" agent of the D brand.

\begin{tabular}{|c|c|c|c|}
\hline \multirow{2}{*}{$\begin{array}{l}n / a \\
n o\end{array}$} & \multirow{2}{*}{ Dust suppression area } & \multicolumn{2}{|c|}{$\begin{array}{l}\text { Concentration of the finished } \\
\text { treatment solution }\end{array}$} \\
\hline & & primary & repeat \\
\hline 1 & Roads and roadsides & $30 \%$ & $5 \%$ \\
\hline 2 & $\begin{array}{l}\text { Processing of bulk materials in bulk, including to } \\
\text { prevent freezing }\end{array}$ & $100 \%$ & - \\
\hline 3 & $\begin{array}{l}\text { Storage of bulk materials in cones in open areas } \\
\text { (treatment with fog generators) }\end{array}$ & $5 \%$ & $5 \%$ \\
\hline 4 & Places of transshipment of bulk materials & \multicolumn{2}{|c|}{$\begin{array}{c}2 \text { liters of } 5 \% \text { solution per } 1 \text { ton of } \\
\text { coal }\end{array}$} \\
\hline
\end{tabular}

\section{Results and Discussion}

Thus, the following conclusions can be drawn from the above material:

1. The existing methods of dust suppression in the extraction, transportation, transshipment and storage of bulk materials are analyzed;

2. Developed and tested in industrial conditions "Methodology for assessing the dusting of road surfaces and the surface of bulk cargo storage stacks at industrial facilities. Determination of the effectiveness of dust suppression means". The results obtained are reproducible and comparable in the conditions of different mining enterprises, which confirms the correctness of the selected technical solutions for the measurement method and the effectiveness of the preventive tool.

3. The use of special preventive measures increases the effectiveness of dust suppression measures to $90 \%$ or more.

4. The use of special preventive measures allows you to reduce the volume of water used for dust suppression, up to ten times, by increasing the time between treatments. If you use special spray nozzles and follow the technology of feeding the dust-suppressing solution, it is possible to reduce the amount of finished solution consumed for processing the rock mass. 
5. Based on the results of the tests performed, the optimal concentrations of the D-grade Anti-dust agent were determined, which allow reducing the amount of blown dust on various surfaces of the roadway sections of the technological road and the surfaces of coal warehouses. The study showed that the use of a preventive agent has not only an environmental, but also an economic effect, since this way it is possible to reduce the operating costs of servicing automatic irrigation equipment.

\section{References}

1. Information and technical guide to the best available technologies for mining and processing ITS 37-2017.

2. Order of the Government of the Russian Federation No. 2841 dated December 15, 2017.

3. Methodological manual for the calculation, regulation and control of emissions of pollutants into the air. SPb., 2005.

4. "Methodology for calculating the assessment of wind erosion and dusting of the ash dump of TPPs", developed by JSC "UralORGES", VNIIOGR, Agrophysical Institute of the Russian Academy of Agricultural Sciences, Yekaterinburg, 1998.

5. "Methodology for calculating harmful emissions (discharges) for a complex of equipment for open pit mining (based on specific indicators)", developed by the National Scientific Center for Mining of the Institute of Mining named after A. A. Skochinsky, Lyubertsy, 1999.

6. "Methodological guide for calculating emissions from fugitive sources in the building materials industry", developed by CJSC "NIPIOTSTROM", Novorosiysk, 2000.

7. Dust suppression at coal enterprises. Magazine - Extractive Industry № 4 (16). 2019.254-255s.

8. The act of conducting industrial tests of the use of "Antipyl" and "Bishofit" means in the conditions of unpaved roads on the territory of the mining allotment of LLC "Mine No. 12". Kiselevsk 2019 .- 22p.

9. The act of conducting industrial tests of the use of "Antipyl" in the conditions of a coal warehouse and technological roads of LLC Berezovsky open pit mine. Prokopyevsky district 2019 .- 25p.

10. The act of conducting industrial tests of the use of "Antipyl" in the conditions of a coal warehouse and dirt roads of JSC "PF Raspadskaya". Mezhdurechensk 2019.- 19p.

11. The act of conducting industrial tests of the use of "Antidust" in the conditions of technological roads Open-pit mine "Chernogorsk" LLC "SUEK-Khakassia". Chernogorsk 2019 .- 27s.

12. The act of conducting industrial tests of the use of "Antidust" in the conditions of technological roads of JSC "Siberian Anthracite". Novosibirsk 2019 .- 17p.

13. "Methodology for assessing the dusting of the road surface and the surface of the stacks of storage of bulk goods at industrial facilities. Determination of the effectiveness of dust suppression means", developed by KuzGTU, Kemerovo, 2019. 